\title{
First record of the European Giant File Clam, Acesta excavata (Bivalvia: Pectinoidea: Limidae), in the Northwest Atlantic
}

\author{
JEAN-MARC GAGNON ${ }^{1}$ and RichaRd L. HAEDRICH ${ }^{2}$ \\ ${ }^{1}$ Collections Division, Canadian Museum of Nature, P.O. Box 3443, Station “D”, Ottawa K1P 6P4 Canada \\ ${ }^{2}$ Department of Biology, Memorial University of Newfoundland, St. John's, Newfoundland A1B 3X7 Canada
}

Gagnon, Jean-Marc, and Richard L. Haedrich. 2003. First record of the European Giant File Clam, Acesta excavata (Bivalvia: Pectinoidea: Limidae), in the Northwest Atlantic. Canadian Field-Naturalists 117(3): 440-447.

Two large bivalve specimens collected in Bay d'Espoir, a deep fjord situated on the south coast of Newfoundland, are described and identified as belonging to the species Acesta excavata (Fabricius 1779). In situ observations onboard the manned submersible PISCES IV and color videos have provided information on the vertical distribution, density and habitat of the species. Maximum abundances of about 15 large individuals $/ \mathrm{m}^{2}$ occurred on sheltered rock outcrops at depth ranging from 550 to $775 \mathrm{~m}$, where warm $\left(6^{\circ} \mathrm{C}\right)$ continental slope water is found. Differences in shape and thickness between the valves of the two specimens appear to be related to the degree of exposure to rock falls (i.e., sheltered versus exposed habitat). Prior to this account, the European Giant File Clam had never been encountered west of the Azores Islands in the North Atlantic.

Key Words: Acesta excavata, European Giant File Clam, Limidae, Northwest Atlantic, fjord, Newfoundland.

Since the original description of the European Giant File Clam, Acesta excavata, by Fabricius (=Ostrea excavata; 1779), records for this species have shown a geographic range extending over most of the Northeast Atlantic, from the Norwegian and Greenland Seas to the Senegal coast (including the Azores and Canary Islands), and into the Mediterannean Sea (Barsotti 1975; Ghisotti 1979; Rocchini 1983; Carcassi 1983). Recorded depths vary between $90 \mathrm{~m}$ and $3200 \mathrm{~m}$, although most occurrences reported since 1969 have been from the 200-800 m depth range (Ghisotti 1979). In the Krosfjord (Norway), the species is frequently encountered on rocky substrates between 100 and $400 \mathrm{~m}$ (Gilmour 1990). In many instances, A. excavata was found in association with the white deep-water coral Madrepora oculata (Rocchini 1983; Carcassi 1983). In the entire Atlantic Basin, only three other living species of Giant File Clams have been recorded: A. bullisi H. E. Vokes, 1963 from the Gulf of Mexico, A. columbiana H. E. Vokes, 1970 from the Caribbean Sea and A. angolensis Adam and Knudsen, 1955 from off the coast of Angola (Vokes 1963a, b, 1963, 1970). To date, Acesta excavata is the only giant file clam species to have been observed in the Northwest Atlantic (Haedrich and Gagnon 1991) .

During a benthic study initiated in 1984 in Bay d'Espoir, a deep fjord situated along the south coast of Newfoundland, Canada, one large, sub-fossilized valve was recovered from sub-surface sediments by a grab, along with fragments of smaller but similar shells. These were tentatively identified to the genus Acesta. Although side-echoing of the depth sounder in this deep narrow fjord precluded reliable depth records, at least $740 \mathrm{~m}$ of wire had been released for the sample.
Bottom-triggered photographs from the same area revealed no such shells on the sediment surface.

In 1985, the availability of a manned submersible allowed a closer examination of an important portion of the benthos on slopes that could not be sampled by conventional methods. Results of two submersible dives down to almost $800 \mathrm{~m}$ have yielded a wealth of information on the fauna in the form of direct in-situ observations, colour videos and still photographs. In addition, one complete live specimen of Giant File Clam (Limidae) was recovered from the rock wall, using the hydraulic arm of the submersible.

This paper describes the specimens collected (valves and soft parts) and confirms their identity as Acesta excavata (Fabricius 1779), based on diagnostic characters of the valves: shape, size and external ornamentation, shape of the ligamental pit and development of the auricles. These specimens are deposited in the Mollusc Collection of the Canadian Museum of Nature, in Ottawa. We also report information on the density and distribution of that species in Bay d'Espoir in relation to substratum type, water temperature, salinity as well as depth. An overall description of the fauna and habitat based on observations obtained during the submersible dives is presented elsewhere (Haedrich and Gagnon 1991).

\section{Description of the Environment}

Bay d'Espoir is a fjord situated along the south coast of Newfoundland, Canada (Figure 1; 47 40' N, 56 08' W). In the eastern portion of its outer basin (near Goblin Head), where specimens of Acesta were found, maximum depth reaches $794 \mathrm{~m}$. There, at least $30 \%$ of the bottom consists of rock walls with slopes greater 


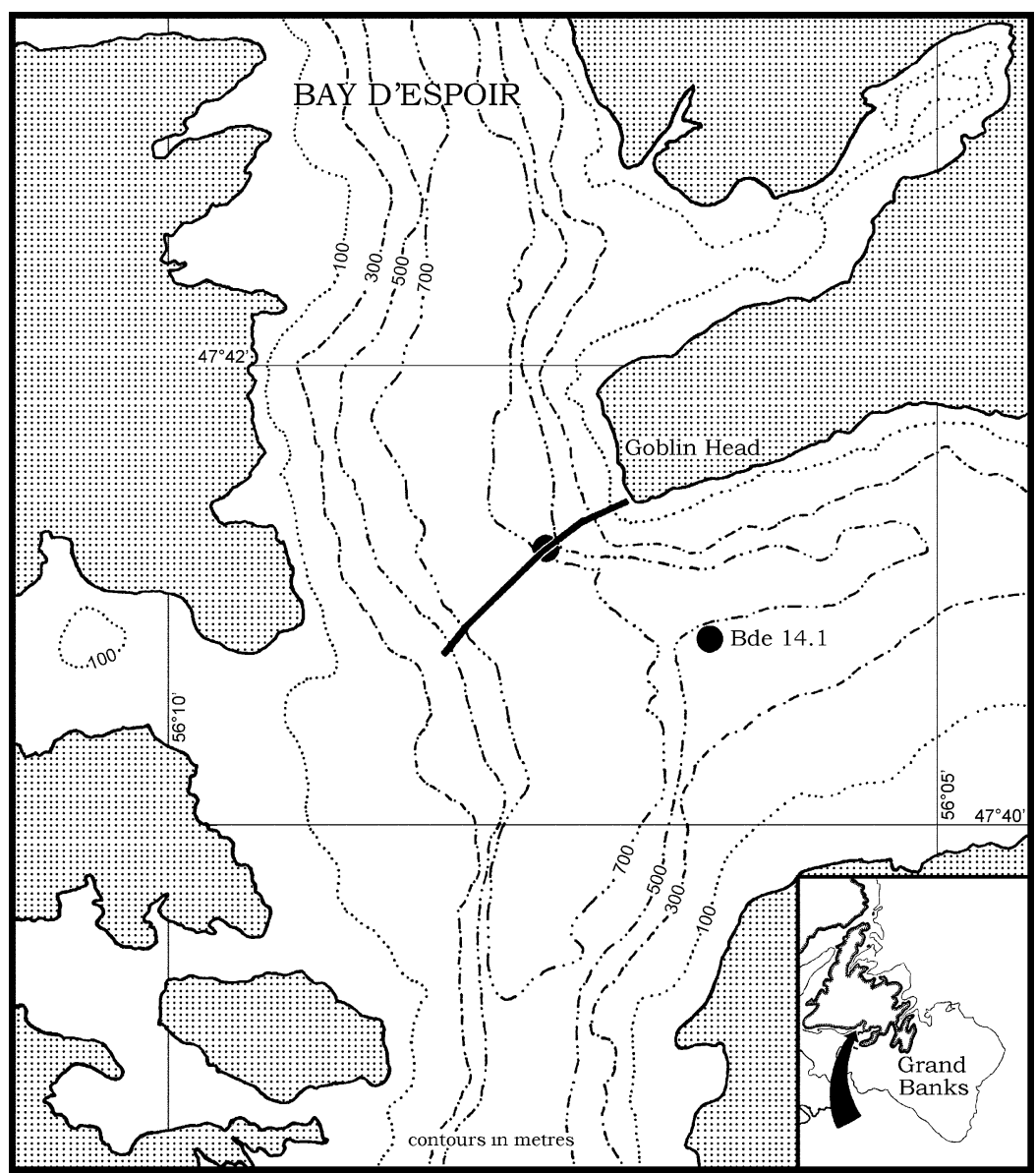

FIGURE 1. Collection sites of the Giant File Clam, Acesta excavata, (filled circles) in Bay d'Espoir, Newfoundland.

than 40 degrees and there are frequent overhangs (Figure 2). In areas where slopes are not as steep, the bottom is mostly made up of silty sediments. Benthic biomass in this basin appears to be important and primarily dominated by suspension and filter feeders such as sponges, several species of anemones, sea pens, the stalked cirriped Arcoscalpellum mitchellotianum, and Giant File Clam (Acesta). This rich invertebrate fauna is supported by a high zooplanktonic biomass (Haedrich and Gagnon 1991), although no estimates of surface primary production are available for this area.

The water column in the outer basin is divided in four distinct layers on the basis of temperature and salinity (Haedrich and Gagnon 1991; Figure 2). Below $250 \mathrm{~m}$, which corresponds approximately to the sill depth at the entrance of the fjord, benthic communities are exposed to a uniformly warm $\left(5.0\right.$ to $\left.6.5^{\circ} \mathrm{C}\right)$, saline $(34.6 \%$ ) and stable water mass derived from the continental slope water. Above, a cold water layer (40$160 \mathrm{~m},-1.0$ to $1.0^{\circ} \mathrm{C}$ ) associated with the less saline
Labrador Current and a transition layer (160-220 m, 1.0 to $5.0^{\circ} \mathrm{C}$ ) maintain the deep isolated layer; only limited exchanges occur with the Laurentian Modified Slope Water from the outside (Hay and deYoung 1983; Richard and Haedrich 1987).

\section{Materials and Methods}

The first specimens of Acesta were collected during a benthic sampling program conducted in the outer deep basin of Bay d'Espoir, Newfoundland, Canada, on 10 December 1984. During that sampling, one large, complete valve and fragments of smaller valves were found in the anoxic, muddy sub-surface sediment of a $0.1 \mathrm{~m}^{2}$ van Veen grab sample from a site to the southeast of Goblin Head, at approximately 600-700 m depth (Figure 1; circa station BdE14.1, $\left.47^{\circ} 40.8^{\prime} \mathrm{N}, 56^{\circ} 06.5^{\prime} \mathrm{W}\right)$. On 26 June 1985 , during a dive onboard the manned submersible PISCES IV, a complete, living specimen was retrieved with the hydraulic arm from the rock wall at the foot of Goblin Head $\left(47^{\circ} 41.2^{\prime} \mathrm{N}, 56^{\circ} 07.6^{\prime} \mathrm{W}\right)$, at $750 \mathrm{~m}$ depth (Fig- 


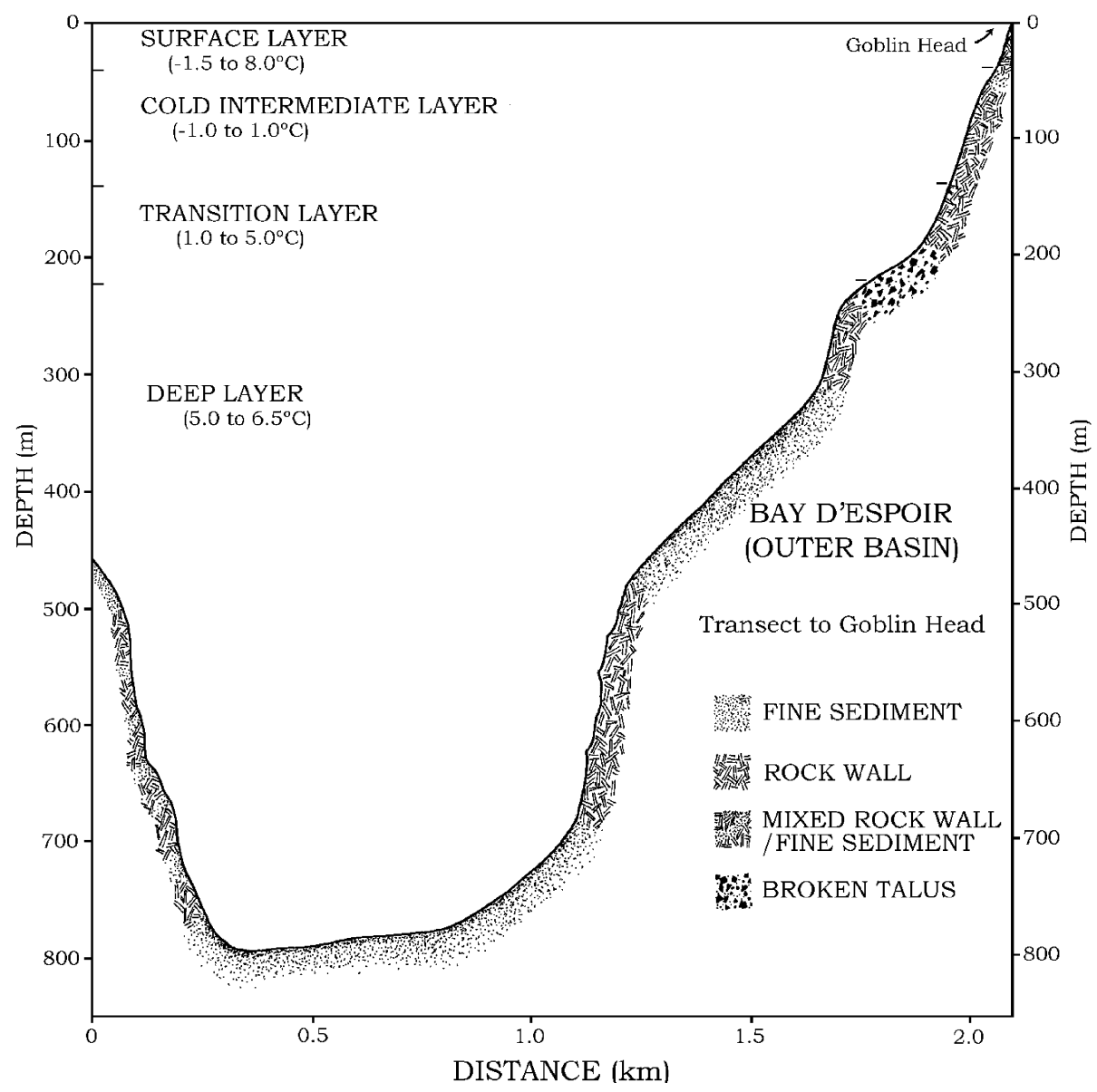

FIGURE 2. Cross-section of the outer basin along the submersible dive transect.

ures 1 and 2). Information on the density and vertical distribution of the species was also recorded during the dive of June 26 and 27 through direct in-situ observations, color videos using an external camera, and color photographs using an external Photosea camera and a hand-held camera through the port-hole.

\section{Results and Discussion \\ Description of specimens}

The first specimen of Acesta excavata (catalogue number CMNML 092957), which was collected with a bottom grab near Station BdE14.1, consisted of a complete right valve (height $112.5 \mathrm{~mm}$, width $81 \mathrm{~mm}$; Figures 3-5). The shell is relatively thin $(0.93 \mathrm{~mm})$, dark grey on the outside and white on the inside (Figures 3 and 4). Deterioration of the inner layer is evident as much of the luster on the nacre layer has disappeared. The external ornamentation of the valve, however, appears intact and is composed of weak, somewhat irregular radial ribs which are more developed in the anterior and posterior region of the valve. In the median portion of the shell surface, these ribs resemble more shallowly impressed, irregular grooves (Figure 3). As described by Vokes (1963a) for Acesta excavata, the straightness of the ribs is mostly affected by the presence of pronounced growth rings. The anterior auricle is highly reduced through the encroachment of the large excavate lunule. The ligamental pit is strongly oblique (Figure 5).

There is a striking resemblance between this specimen from Bay d'Espoir (Figure 3) and those illustrated by Barsotti (1975), Ghisotti (1979) and Rocchini (1983). In fact, shell characteristics for this specimen correspond well to those of specimens of Acesta excavata examined from the Northeast Atlantic (including the Azores Islands), the Norwegian Sea, the Mediterranean Sea (Table 1). Its shell height/width ratio (1.39) falls within the variation of that observed in these European specimens $($ mean $=1.34$, standard deviation $=0.049, \mathrm{n}=27$ ).

The second specimen (catalogue number CMNML 092958; Figures 6-8) was a complete, living individual, only slightly damaged during its recovery by the hydraulic arm of the submersible. The damage was 
mainly due to the force necessary to break the byssal attachment to the rock wall. The left valve, however, shows signs of shell damage sustained by the animal earlier in its life (Figure 6). This past injury apparently resulted in abnormal growth of the animal. While the shell height $(112.0 \mathrm{~mm})$ is very similar to that of our first specimen, it is significantly wider $(94.5 \mathrm{~mm})$, with a height/width ratio of 1.19 . The animal was originally injured in the posterior region of the shell (see Figure 6 , shell margin at height $34 \mathrm{~mm}$ ), causing a greater growth in that region of the shell relative to the rest and resulting in the wider, less elongated appearance of the specimen. The pathological condition of this specimen is also reflected by the distorted margin of the lunule (Figures 7-9). Valves are also thicker (1.1 $\mathrm{mm}$ ) than that of the first specimen, and mostly white. Otherwise, the ornamentation of the shell, the shape of the ligamental pit and muscle scars are comparable to those of the first specimen. The differences observed between the two specimens may be the result of living in a sheltered vs. exposed habitat. As discussed in the following section, animals living under overhangs are protected from rock falls.

Very little information is available in the literature on the soft parts of Acesta excavata, hard parts being typically used to identify bivalves. Figures 9-11 show some important characteristics such as the long pallial tentacles along the mantle margin (typical of all Limoida; Gilmour 1990), eight strong byssal treads and the deeply grooved foot. When freshly collected, margins of the mantle and its tentacles were bright orange, the remaining soft parts being mostly pale orange. Gilmour (1990) examined the significance of foot reversal in Limoida and described the arrangement of muscles on freshly collected Acesta excavata specimens from the Krosfjord in Norway. The overall pattern of muscle disposition on our specimen corresponds well with that described by Gilmour. The slight difference in the position of the anterior pedal retractor and the not readily visible anterior byssal retractor are not believed to be significant (T. H. J. Gilmour, personal communication).

\section{In situ observations}

To our knowledge, this is the first in situ observation of the European Giant File Clam, Acesta excavata. The species was encountered on rock walls and outcrops only in the deepest part of the outer basin, between approximately 550 and $775 \mathrm{~m}$. Water temperature within that depth range was $6.3 \pm 0.1^{\circ} \mathrm{C}$. Because rock faces are infrequent between 500 and $300 \mathrm{~m}$ (Figure 2), it is not possible to establish an accurate upper limit to the bathymetric distribution of A. excavata in Bay d'Espoir.

In areas where the rocky substrate is exposed to sedimentation, and potentially to rock falls (Figure 12), total animal biomass appears much lower than in sheltered areas (Figure 13). The Giant File Clam shared these habitats primarily with anemones and sponges; colonial anemones were particularly dominant under overhangs (Figure 13). We found no indication of the presence of the white coral Madrepora oculata which is frequently found in association with Acesta excavata in the Northeast Atlantic (Fosså and Mortensen 1998) and the Mediterranean (Parenzan 1974; Ghisotti 1979; Rocchini 1983; Carcassi 1983). Estimates of density are difficult to obtain due to the patchy distribution of Acesta on the rocky substrate and the lack of a reference scale when surveying with the submersible. When present, however, densities appear to vary from few to 10-15 individuals per metre $^{2}$; this is probably a conservative estimate since only the large individuals that could be distinguished from the orange anemone Actinauge sp. were counted.

\section{Origin of the Northwest Atlantic population}

The discovery of Acesta excavata off southern Newfoundland represents a significant extension to its previously known geographic range by probably more than $2100 \mathrm{~km}$. This Newfoundland population of A. excavata may be a relict from a previously wider distribution, although many deepwater species found in Bay d'Espoir are typically found on the Eastern Canadian continental slope and the St. Lawrence Channel. Alternatively, A. excavata may have a more

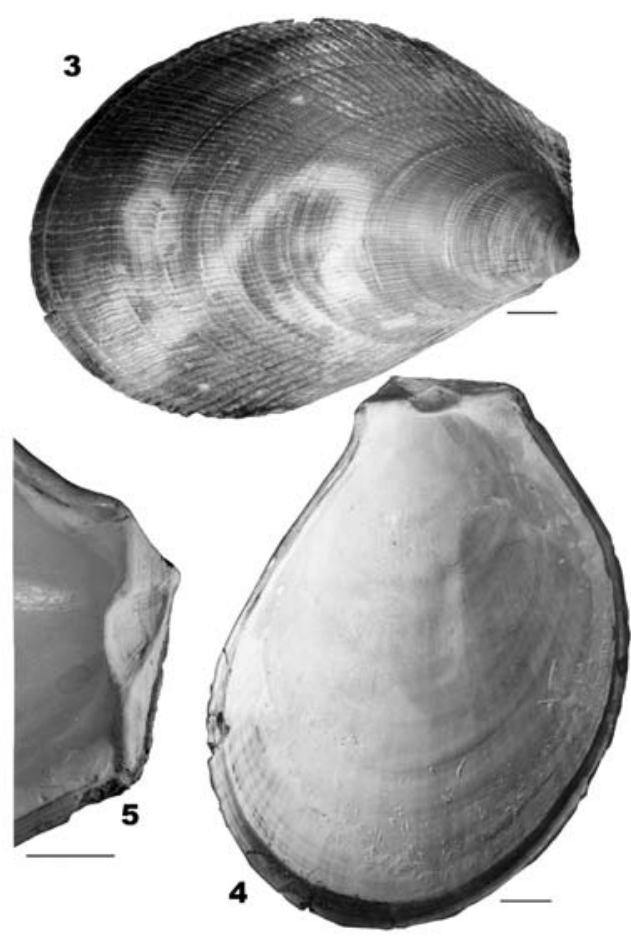

FIGURES 3-5. Acesta excavata specimen \#1 (catalogue number CMNML 092957), right valve; height: $11.25 \mathrm{~cm}$, width: $8.0 \mathrm{~cm}$. 3 . Exterior view. 4 . Interior view. 5. Hinge view. 


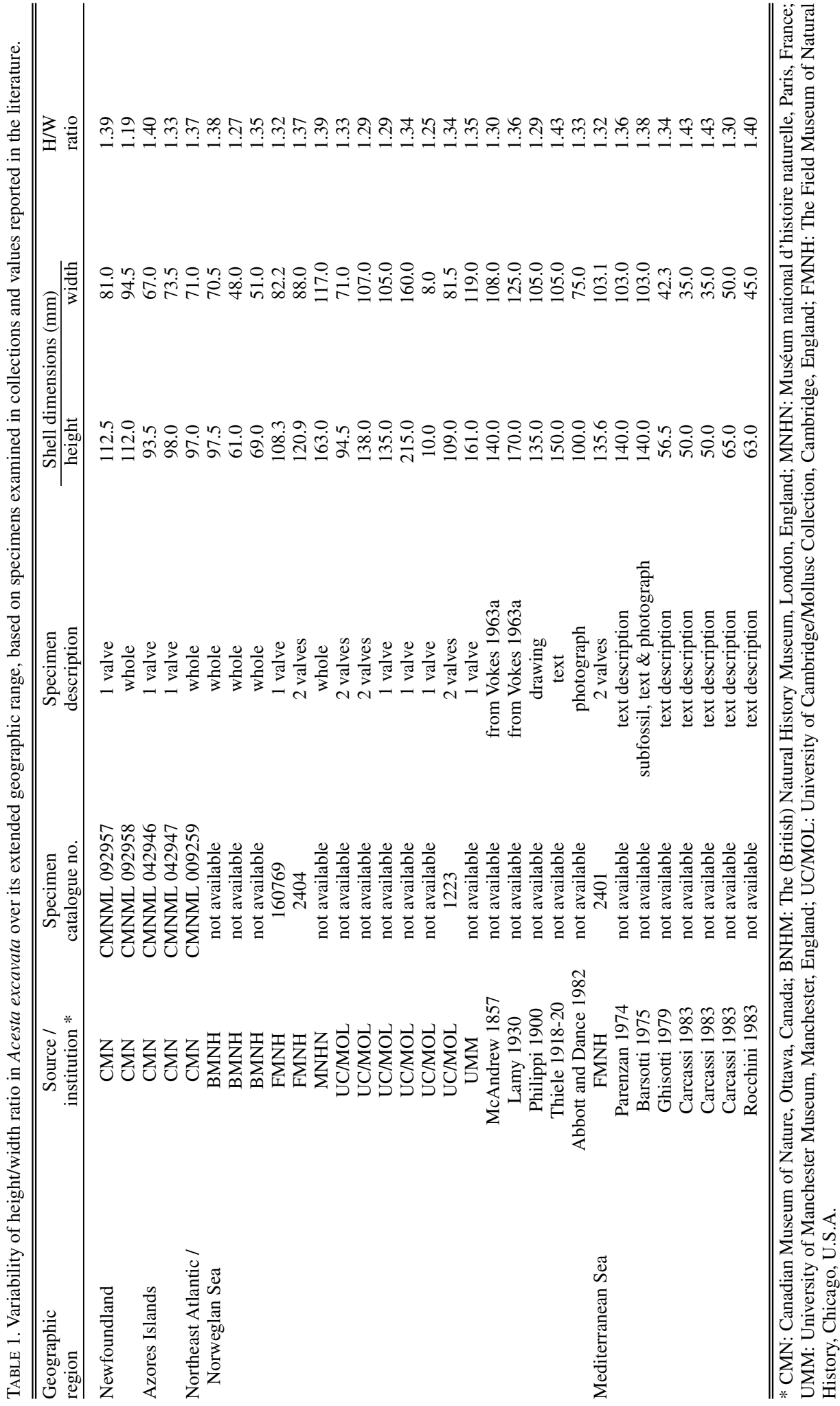




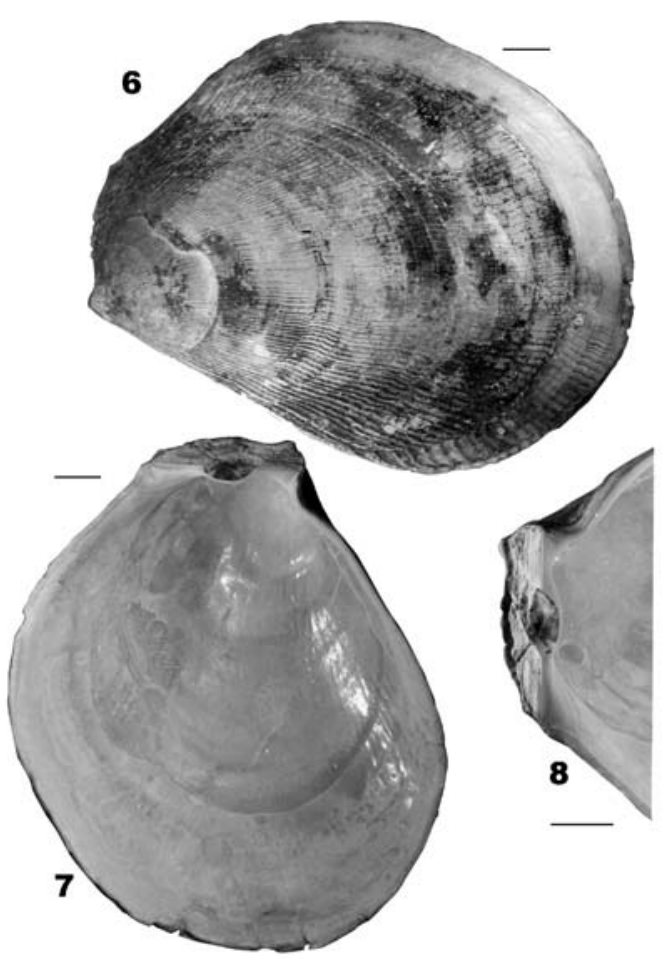

Figures 6-8. Acesta excavata specimen \#2 (catalogue number CMNML 092958), left valve; height: $11.2 \mathrm{~cm}$, width: $9.45 \mathrm{~cm}$. 6. Exterior view. 7. Interior view. 8 . Hinge view of left valve.

continuous distribution in the Northwest Atlantic at present but has only been recovered from Bay d'Espoir.

There have been relatively few surveys of bathyal communities in the Northwest Atlantic (Grassle et al. 1975; Haedrich et al. 1980), and particularly on deepwater hard substrata along the eastern Canadian and Greenland continental slopes (Houston and Haedrich 1984). The few surveys that have been undertaken along the eastern Canadian and United States slopes, including photographic explorations of the wreck of the RMS TITANIC (P. Pocklington, personal communication), did not reveal the presence of $A$. excavata. Further sampling surveys are necessary in areas of the Northwest Atlantic where suitable A. excavata habitats (e.g., deep-basin bays, continental slope and bathyal rocky outcrops) exist to determine the full extent of its distribution. Also needed is information on the larval stages of A. excavata and their dispersal in the water column, to establish whether they occur in prominent ocean current systems between the Northeast and Northwest Atlantic and could account for the establishment of the European Giant File Clam in Bay d'Espoir, Newfoundland.

\section{Acknowledgments}

We thank the other scientific members of the dive team - Jack Foley, Roy Ficken, Bob Hooper and David Schneider - for their help and participation in the field program onboard the Pandora/PISCES IV. This work would not have been possible without the logistic support of the captains and crews of the C.S.S. DAWSON and Pandora/PISCES IV; ships and submersible were made available to us by the Department of Fisheries and Oceans Canada (DFO). We further extend our gratitude to Roy Ficken for providing us with his expertise as photographer during the dives and subsequently, when producing figures for this publication. We also thank Harold E. Vokes and Thomas Gilmour for their help in confirming the identification of the specimens; Rudolph Scheltema, Bernard Sainte-Marie, David Barr, André Martel and four anonymous reviewers for their comments on the manuscript, and Leisha Clarke-Doherty and Mélanie Gaudet for editorial assistance. This work was funded in part by a grant from the Natural Sciences and Engineering Research Council (NSERC) to R. L. H. and a DFO/NSERC post-doctoral fellowship to J.-M. G.

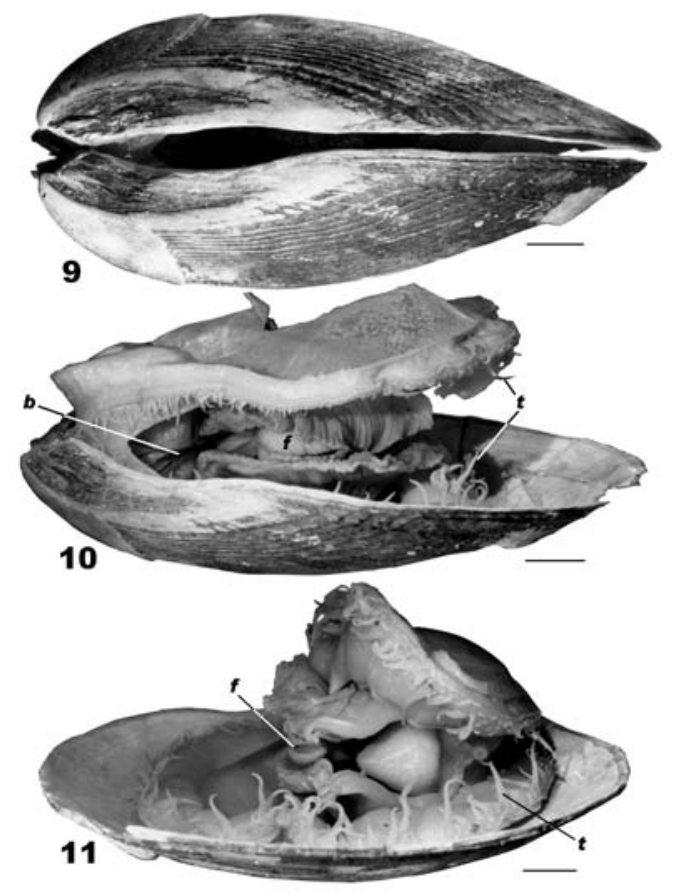

FIGURES 9-11. Acesta excavata specimen \#2 (catalogue number CMNML 092958). 9. Anterior view of complete animal. 10 and 11. Anterior and ventro-posterior views of animal in right valve, showing byssus $(b)$, grooved foot $(f)$, and pallial tentacles $(t)$. 

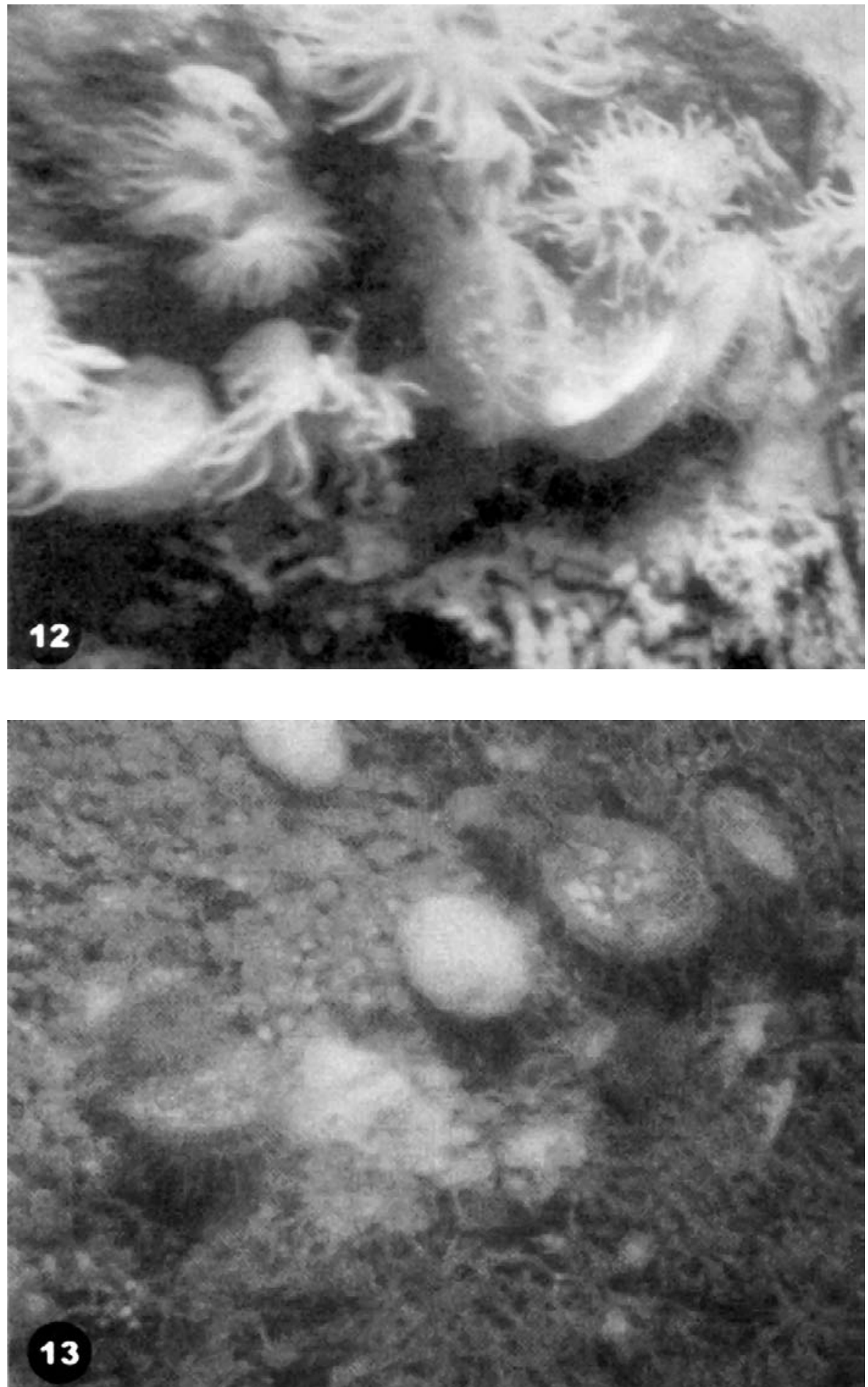

FiguRES 12-13. Living Acesta excavata on the rock walls of Bay d'Espoir. 12. Sheltered under overhang, circa 650 m. 13. Exposed, circa $550 \mathrm{~m}$. 


\section{Literature Cited}

Abbott, R. T., and S. P. Dance. 1982. A compendium of seashells. E. P. Dutton, New York, New York.

Barsotti, G. 1975. Superfamilia Pectinacea Rafinesque, 1815, Fam. Limidae. La Conchiglia, Roma, 7 (71-72): 3-6.

Carcassi, A. 1983. Uteriore ritrovamento di Acesta excavata vivente in Mediterraneo. Bollettino Malacologico 19: 264.

Fabricius, J. C. 1779. Reise nach Norwegen: Hamburg. ILXIII, 388 pages.

Fosså, J. H., and P. B. Mortensen. 1998. Artsmangfoldet på Lophelia-korallrev og metoder for kartlegging og overvåkning. Havforskningsinstituttet (Burgen), Fisken og Havet NR. 17, 95 pages.

Ghisotti, F. 1979. Ritrovamento di Acesta (Acesta) excavata (Fabricius, 1779) vivente in Mediterraneo. Bollettino Malacologico 15: 57-66.

Gilmour, T. H. J. 1990. The adaptative significance of foot reversal in the Limoida. Pages 249-263 in The Bivalvia Proceedings of a Memorial Symposium in Honour of Sir Charles Maurice Yonge. Edited by B. Morton. Hong Kong University Press, Hong Kong.

Grassle, J. F., H. L. Sanders, G. T. Rowe, and T. McLennan. 1975. Patterns and zonation: a study of the bathyal megafauna using the research submersible Alvin. Deep-Sea Research 22: 457-481.

Haedrich, R. L., and J.-M. Gagnon. 1991. Rock wall fauna in a deep Newfoundland fiord. Continental Shelf Research 11: 1199-1207.

Haedrich, R. L., G. T. Rowe, and P. T. Polloni. 1980. The megafauna in the deep sea south of New England, U.S.A. Marine Biology 57: 165-179.

Hay, A. E., and B. deYoung. 1983. An oceanographic flipflop: deep water exchange in Fortune Bay, Newfoundland. Journal of Geophysical Research 94: 843-853.

Houston, K., and R. L. Haedrich. 1984. Abundance and biomass of macrobenthos in the vicinity of Carson submarine canyon, northwest Atlantic ocean. Marine Biology
82: 301-305.

Lamy, E. 1930-31. Révision des Limidæ vivants du Muséum National d'Histoire Naturelle de Paris. Journal de Conchyliologie 74: 89-269.

McAndrew, R. 1857. Report on marine testaceous Mollusca of the Northeast Atlantic and neighboring seas, and physical conditions affecting development. Report of the British Association for the Advancement of Sciences. Pages 101144.

Parenzan, P. 1974. Carta d'identità delle conchiglie del Mediterraneo. Volume II Bivalvi, prima parte. Bios Taras Publishing, Taranto, Italy. Pages 122-123, plate 26.

Philippi, E. 1900. Beiträge zur Morphologie and Phylogenie der Lamellibranchier. III. Lima und ihre Untergattungen, Zeitschift der Deutsche Geologische Gesellschaft 52: 619-639, Plate 24.

Richard, J. M., and R. L. Haedrich. 1987. The mesopelagic fish faunas of two fjords differing in physical oceanography. Pages 193-200 in Proceedings of the 5th Congress of European Ichthyologists. Edited by S. O. Kullander. Stockholm.

Rocchini, R. 1983. Acesta excavata (Fabricius, 1779), nuovo ritrovamento in Mediterraneo. Bollettino Malacologico 19: 83-86.

Thiele, J. 1918-20. Familia Limidæ. Conchulien-Cabinet. Verlag von Bauer \& Raspe, Nürnburg, Germany. 66 pages. 10 plates.

Vokes, H. E. 1963a. Studies on tertiary and recent giant Limidæ. Tulane Studies in Geology 1: 73-92.

Vokes, H. E. 1963b. Additions to a catalogue of the described recent and tertiary species of Acesta and Plicacesta. Tulane Studies in Geology 2: 18-20.

Vokes, H. E. 1970. Two new species of deepwater bivalves from the Caribbean Sea. The Veliger 12: 357-361.

Received 10 September 2002

Accepted 6 January 2004 